period of the year is so rapid, and the sap circulates through the branches in such abundance, that the comparatively small quantity consumed by these plant lice seems scarcely to be missed. In a few days the young leaves expand, when the insects are distributed over the foliage, and usually attract no further notice.

All the lice hatched in the spring are females, and they reach maturity in ten or twelve days, when they commence to give birth to living young, producing about two each every day for two or three weeks, after which the older ones die. The young locate about their parents and mature in

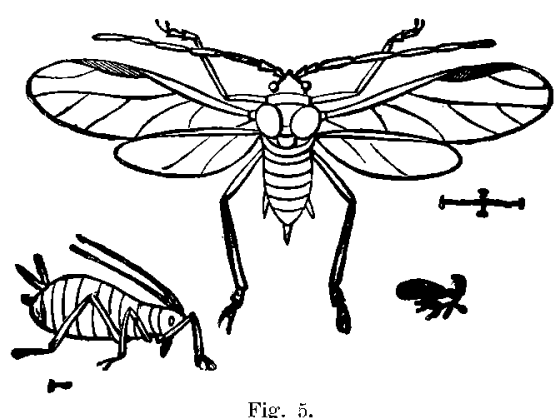

Fig. 5. ten or twelve days, when they also. become mothers as prolific as their predecessors. As the season advances some of the females acquire wings, by means of which they fly to other trees, where they found new colonies. In figure 5 both winged and wingless specimens are shown much magnified. Late in the autumn males, as well as females, are produced,

and the work of the year closes with the deposit of eggs as already described. Were it not for the activity of Lady-birds and other useful predaceous insects, which appear early upon the scene and devour multitudes of these lice, they would soon swarm on every leaf of our apple trees and become a source of serious trouble.

\title{
NOTES ON THE EARLY STAGES OF CALOPTERON RETICULATUM, Fabr.
}

BY D. W. COQUILLETT, WOODSTOCK, ILL.

On the Ioth of July I found a pupa of this species suspended by the hind end of its body beneath a log. The larval skin was rent and worked backward, but still retained nearly its original shape and color, and by comparing it with certain larvæ which I have frequently met with in similar situations, there is no doubt in my mind but that these latter belong to the above species.

These larvæ very closely resemble that figured by Packard on page 465 of his "Guide" (fig. 432), which in the text on the succeeding page is referred to Photuris. The dried specimens now before me measure 
about $\mathrm{I} 2 \mathrm{~mm}$., and are of a dull purplish-brown color; venter pale yellow, tinged with pink and marked with a brownish stripe on each outer edge, and with two rows of brown spots, these not extending upon the first three segments ; head retractile, dull blackish, the region of the jaws polished brown, and furnished with four black prickles, the upper two of which are placed transversely, the lower two longitudinally.

The pupa mentioned above tapered quite regularly from the head to the tail, and was of a blackish color, shaded in places with whitish; segment one flattened above, and on each outer edge, near the anterior end of the segment, are two white, fleshy horns, the posterior ones the longest ; on each posterior angle of this segment is a long, white horn, curved backward; on the anterior part of each abdominal segment is a sharp transverse ridge, which unites at right angles with a subdorsal ridge that extends leagthwise across the segment; near the places where these ridges meet is a low whitish tubercle; a stigmatal row of whitish horns, two to each segment, curved forward, those on the first abdominal segment the longest, those on each succeeding segment shorter than those on the segment preceding it ; antennæ-cases curved, longer than the leg-cases, white, marked with black; length, I $3 \mathrm{~mm}$.

The beetle issued from the above pupa on the 2 ist of July, and was of the variety terminale of Say.

\section{THYRIDOPTERYX EPHEMERCEFORMIS, HAWORTH.}

HY FREDERICK CLARKSON, NEW TORK CITY.

By the kindness of Mr. Donnelly, the very efficient head gardener of the Central Park, of this city, I am put in possession of sixty cocoons of the "Basket-worm." They were taken from the terminal twigs of a sapling Sycamore Maple and Horse Chestnut growing on the low land in the immediate vicinity of the zoological garden. The cocoons hung in clusters on every twig, and as they had excited considerable curiosity, the gardener permitted them to remain until about the period of egg-hatching. I have supposed it might be of interest to the subscribers of the CANADIAN EnTomologist to have the result of my examination of these cocoons. Ten of them had been occupied by the male, as attested by the puparium within. In about an equal number I found the broken shell-case of the female, all else having been devoured by parasites, some of which, in pupa condition, were found within the cocoons. The remainder of the cocoons 